\title{
The Impact of Unsystematic Risk on Stock Returns in an Emerging Capital Markets (ECM's) Country: An Empirical Study
}

\author{
Mohamed Masry ${ }^{1} \&$ Heba El Menshawy ${ }^{1}$ \\ 1 Accounting and Finance Department, Faculty of Business Administration, Arab Academy for Science and \\ Technology (AAST), Alexandria, Egypt
}

Correspondence: Mohamed Masry, PhD, MA, MBA, BA in Finance, Accounting and Finance Department, Faculty of Business Administration, Arab Academy for Science and Technology (AAST), P.O Box 1029-Miami, Alexandria, Egypt. Tel: 203-556-5429/548-1163.

Received: Decemebr 20, 2017

Accepted: January 15, $2018 \quad$ Online Published: January 17, 2018

doi:10.5430/ijfr.v9n1p189

URL: https://doi.org/10.5430/ijfr.v9n1p189

\begin{abstract}
In this study, we aim to introduce behavior of unsystemayic risk and its forecasting ability in prediction of future return in Egyptian Stock Exchange (ESE) as an Emerging Capital market (ECM), over the period of 2006 to 2015. We measure equally weighted unsystemayic volatility by following the Campbell's (2001) Indirect Method, by considering market size and weekly basis. Our results reveal that unsystemayic risk is the biggest component of total volatility and show no trend, although market volatility has a slow decreasing trend in this period. We also find that small size stocks have slightly higher volatility than the big size stocks but both portfolios have similar idiosyncratic risk behavior. Finally, our analyses about the predictive ability of various measures of unsystematic risk provide evidence that unsystematic risk volatility is not a significant predictor for future return in ESE.
\end{abstract}

Keywords: unsystemayic risk, Emerging Capital Markets (ECM’s), volatility, Egyptian stock exchange

\section{Introduction}

Asset pricing is a central issue in finance. Traditionally, stock prices were considered to be determined by a simple intersection point between demand and supply curves; yet this approach abstracts from numerous features of real markets, including information asymmetries, differing expectations of market participants, the trading setup, and fluctuations in liquidity. The study of market microstructure endeavors to understand the pricing process taking place on real markets whilst accounting for the special features of individual markets, particularly the trading setup.

Market microstructure studies are relevant to Emerging Capital Markets (ECM). Considering that the discipline is relatively new, the majority of publications tended to focus on developed markets such as US and UK ones. Yet, the discipline may be further enriched through studies using emerging markets data since one may expect differences between the microstructure effects of stock market trading in emerging economies and those in the industrial economies. As compared with developed stock markets, ECM tends to exhibit: higher serial correlation, less frequent trading, slower adjustment of prices to news, and indirect evidence of more insiders trading (Masry, 2017).

The nature and performance of financial systems in ECM must be judged in relation to an individual country's level of development. Whether these financial systems are relatively simple or more complex. The primary role of the financial system in any economy is to mobilise resources for productive investment. The financial system provides the principal reasons for transfering funds or savings, from individuals and companies to private enterprises, farmers, individuals, and others in need of capital for productive investment. An efficient financial system channels transfers resources into activities that will provide the highest rate of return for the use of the funds. These resources stimulate economic growth; provide enterprises with the ability to produce more goods and services and generate jobs. A well performed and formal financial market offer to investors a variety of short and long term investment instruments by providing them with qualified financial intermediaries that enable individuals to make reasonable and adequate decisions about the risks and rewards regarding the invesments of their funds. These instruments package risk and returns effectively so that the investors who wish to participate in a well-structured and appropriate market can do so.

Unsystematic risk fluctuation is a component of the total fluctuations in stock returns. Many studies were made to look into what is represented by unsystematic risk fluctuation is relative to the whole fluctuation as well as studying 
the general trend of unsystematic risks in different markets. Within the same regard, the study of Camplbell et al (2001) which used monthly data from the year 1962 to 1997, and by applying to the U.S market, proved that the average unsystematic fluctuation represented the most important part of the average whole fluctuations increasing notably in this period as the study proved that the market fluctuations are not a general trend as results confirmed, while studies of Malkiel and Xu (2003) and Brandt et al (2010) proved the increasing unsystematic fluctuation within the 1990s and lack of fluctuation as a general trend. Unsystematic risk pricing represents a great importance in finance literature. Study of Levy (1978) at the theoretical level proved the effects of unsystematic risks on asset prices equilibrium, also the study of Merton (1987) proved the ability of using unsystematic fluctuations to explain expected stock returns, if investors implement effective diversification. Accordingly, the more unsystematic variance the more the required rate of return.

ECMs attract numerous investors mainly during times of financial instability in developed markets. Moreover, investors seeking to diversify their portfolios often discover ECM attractive characteristics, such as low correlations with developed markets and higher average sample yields, resulted in a substantial increase in capital flows (Bekaert and Harvey, 1997). Despite this intense increase in capital flows, little research has examined the impact of unsystematic risk on stock return in these markets. Bekaert and Harvey (1997) suggest that ECM exposure shows both greater stock return persistence and higher volatility than developed markets.

Despite the fact that many studies have been made regarding the financial markets of developed countries, very few have been conducted in the case of ECMs. In this sense, very few are the studies that focus on the analysis of financial risk of capital markets in ECMs and particularly at in the Middle East and North Africa region (MENA). In view of the questions posed by the study, Egypt was selected for a number of reasons. Egypt is that has been neglected in the existing literature, a country in (MENA) and an ECM country as well. The choice of emerging markets generally, and the Egyptian stock exchange specifically, is motivated by first the fact that this block of economies is under-researched, but second the institutional environment in which these markets are operating attracts inefficiencies, as indicated by the study of (Masry,2016b).Masry (2016b) verified that the lack of the comprehensive and appropriate institutional setups that support financial markets in most emerging markets recommends that prices will be more predictable. Extending market microstructure research to focus on ECMs, as the study of Masry (2017), stated that ECM show distinctive features that support investors perform diversification within their portfolio. Standard statistical tests may not entirely reveal the possibility for abnormal return to be attained in developing markets because of some distinctive characteristics.

While considerable research has been done on the time series relationship between expected market return and unsystematic risk (see French, Schwert, and Stambaugh,1987; Glosten et al., 1993), limited empirical evidence is available on unsystematic risk and that too mostly for the developed markets. Although the findings are interesting, developed markets alone should not determine the role of unsystematic risk. It is important to study other stock markets around the world that can provide further evidence.

Therefore, this study focuses on the previously neglected markets: the ECMs. These markets are gaining importance because global investors tend to combine them with their developed market investments for risk diversification purpose. It should be interesting to look at the evidence from these markets as the empirical results, at times, might conflict with the available international work. This study constitutes an important objective when considering the increased interest in such markets on part of finance practitioners. This study drives its importance from the need to discuss the impact of unsystematic risk on stock return in an ECM's Country, i.e., The Egyptian Stock Exchange (ESE), The profitability of these strategies applied in emerging markets will be compared to the profitability of comparable strategies from previous studies of worldwide undeveloped and developed markets. Information and data whether historical, private or current, play a big role in taking investment decision, as it supports investors to take the right decision that help them to achieve their goals, and suits their personal circumstances.

The problem of the study is represented in the identification of the extent degree of importance of the unsystematic risk in the Egyptian stock market. Accordingly, we may identify the following questions under the current study problem:

1/1.Do unsystematic risk impact on total risks differs depending on the stocks size?

$1 / 2$. Is there any presence of any trend of the unsystematic risk in the period of 2006 to 2015 ?

1/3. Is the forecasting ability of unsystematic risk is possible in an Emerging Capital Markets (ECMs) country?

In ECMs, there is a virtual absence of empirical work on unsystematic risk. It is important for policy makers, global investment managers as well as the academia to understand if there are any significant differences in the 
unsystematic risk patterns in stock returns for mature and emerging markets and whether these observable patterns can be explained by common risk factors. Any empirical finding on the issue shall not only provide better insights about market efficiency and asset pricing but also has implications for designing investment strategy.

Studying the relationship between unsystematic risks and stocks returns in the Egyptian stock market, as an indicator and good practical example for ECMs, help researchers and investors whether individual or investment organisations to take suitable decisions through identifying whether unsystematic risks shall be priced or not. Also this study paves the road to carry out more studies about unsystematic risks in the Egyptian stock market. Accordingly and depending on questions to be answered later, the main aim of the current study is to identify unsystematic risks importance and the necessity in considering it in stock valuation in the Egyptian stock market. The main aim of this article is to fill the gap in asset pricing literature, which can be achieved through the accomplishment of the following objectives:

1/1. Identifying how far unsystematic risks affect the whole risks depending on stocks sizes differences.

1/2. Determine the presence of any trend of the unsystematic risk in the period of 2006 to 2015.

1/3. Investigate the forecasting ability of the unsystematic risk in the ESE, as an example, for an EMC country.

\section{Literature Review}

Unsystematic risks study received high concern from researchers in the field of finance. Finance literature early witnessed Empirical evidence of unsystematic risks prices through cross sectional analysis of stocks, by means of study of Lintner (1965) and Douglas (1969), proved the significance of the residual contrast for market model when explaining average shares through cross section analysis. On the other hand, studies of Miller and Scholes (1972) and Fama and Macbeth (1973) discovered statistical gaps in these studies analyses. While study of Lehmann (1990) reconfirmed results of the study of Douglas (1969) after a comprehensive economic analysis. However, researchers gave more concern in studying the differences in unsystematic risks through cross sectional analysis. The directions of many studies focused on the firm characteristics including institutional ownership. Studies discussed institutional ownership's effect on unsystematic risks through cross sectional analysis including study of Brandt et al (2010), which found a positive relationship between unsystematic risks evaluation and institutional ownership. In contrast, results of study of Vozlyublennaia (2011) proved that high number of shares owned by institutional ownership is accompanied by unsystematic risks, but increase or decrease in number of stocks owned by institutional ownership by time can't affect the company's unsystematic risks and profitability in the future.

French et al. (1987) studied the intertemporal relationship between the expected risk premium on the stock portfolio and stock market volatility using data on the common shares of the New York Stock Exchange (NYSE). The sampling period of the study was from January 1928 to December 1984. The monthly variance of the market return was calculated as the sum of the daily squared returns plus twice the sum of the products of the adjacent returns. They decomposed the calculated monthly volatility estimate into predictable and unpredictable components using univariate autoregressive integrated moving average models. Their results showed a significantly negative relationship between the expected risk premium and the unpredictable volatility. This negative ex post relationship has been interpreted as indirect evidence of a positive ex ante relationship between risk premium and volatility. Glosten et al. (1993) examined the time series relationship between conditional average returns and the conditional volatility of excess stock returns. The sampling period was from 1951 to 1989 . They argued that the standard GARCH-M model was not rich enough to capture the properties of the time series of excess monthly returns, and thus modified them taking into account the seasonal effects, of incorporating the impact of nominal interest rates on volatility and allowing unexpected positive or negative returns to have a different impact on it. Using the modified GARCH-M model, they stated there is a negative relationship between conditional mean yield and conditional variance.

In addition, studies by Brown and Kapadia (2007) and Irvine and Pontiff (2009), Fink et al (2010) proved a negative relationship between unsystematic risks and different profitability scales, also study of Jiang et al (2009) proved a negative relationship between unsystematic risks and stocks profits. On the other hand, study of Cao et al (2008) proved that there is a profit increase resulting from the increase in unsystematic risks fluctuations and share turnover. Studyof Brown and Kapadia (2007), Dennis and Strickland (2004) proved a positive relationship between unsystematic risks and share turnover and size .In the same regard, study of Malkiel and Xu (1997) proved that small stocks portfolios are more fluctuating than big stocks ones, and also proved that unsystematic risks fluctuations were strongly related to the organisation's size,and similarly, study of Drew and Veeraraghavan (2002) proved that small size organisations shares have high unsystematic risks fluctuations and generate the higher returns than markets of Hong Kong, India, Malaysia and Philippines. Besides, study of Drew et al (2002) proved that small size 
organisations whose lower unsystematic risks fluctuations generate higher returns than bigger ones registered in Shanghai stock market.

Study of Malkiel and Xu (2003) proved that unsystematic risks fluctuations can be related to the institutional owner. And that there is a positive relationship between unsystematic risks fluctuations and expected returns growth rate, while the study of Vozlyblennaia (2013) proved a non-significant statistical relationship between institution's characteristics, book to market, leverage size, the institutional ownership, the earnings per- stock and turnover and unsystematic risks.

Unsystematic risks received more concern from researchers all over the world, as there are many studies that used European countries as a research site in application. For instance, in Germany and the U.K, one can apply the study Drew et al (2006) on all listed companies in Germany and the U.K from 1991 to 2001 by using monthly data of unsystematic risks fluctuations and stocks returns, the study proved that unsystematic risks fluctuations are a good tool for explaining expected returns as well as study of Angelidis and Tessaromatis (2008)that applied to all shares trended in London stock exchange market from 13/12/1979 to 30/09/2003, depending on monthly data for unsystematic risks fluctuations and stocks returns by the study of Campbell et al,. Also the study proved that small capitalisation stocks fluctuations affect assets pricing, as well as the small stocks of unsystematic risks fluctuations depend on the market returns.

However, in Spanish stock exchange market, study of Miralles et al (2012) was applied from 1987 to 2007 and consisted of 207 stocks. Monthly data for fluctuations and stocks returns appeared as the study proved that unsystematic risks constitute a great part of the whole risks in addition to a positive relationship between unsystematic risks and stocks expected returns. While in the Turkish market, study of Fazil and Ipek (2013) applied to Istanbul stock exchange (ISE). The study sample included ISE National -100 index, from January 2007 to December 2010 and depended on monthly data for idiosyncratic fluctuations and stocks returns by following study of Campbell et al (2001). Also, the study proved that there is no general trend for unsystematic risks fluctuations. And it also found that unsystematic risks constitute a great percentage of all risks, and that unsystematic risks fluctuation disability depends on the expectation of stocks returns.

In the context of ECMs, there is empirical evidence of the relationship between expected returns and unsystematic risks. De Santis and Imrohoroglu (1994) studied the relationship between market risk and expected return in emerging financial markets. Results based on local results foreign currency denominated returns have not shown significant positive reward for the return relationship. Chiang and Doong (2001) studied the empirical relationship between stock returns and unsystematic risks for seven Asian stock markets. One of the countries in the sample was South Korea. Using French et al. (1987) methodology, they found that in four out of seven sample markets there were a significant relationship between stock returns and unsystematic risks. In South Korea, stock market returns were not significantly explained by the unexpected volatility. They also used Threshold Autoregressive GARCH (TAR-GARCH) Template to analyse the relationship between returns and volatility. They found that the estimated conditional volatility was not able to predict future expected returns. However, South Korea was an exception in case of a series of monthly returns. Lee, Chen, and Rui (2001) examined the relationship between return and volatility in China by adjusting the GARCH-in-Mean (GARCH-M) model. Their results indicated that there is no relationship between expected return and unsystematic risks as predicted by asset valuation models. Shin (2005) studied the relationship between expected returns and unsystematic risks of ECMs using parametric parameters and semi-parametric GARCH in the medium model. Their sample included Brazil, India, Korea and others emerging economies.And as a result, they found that there is a positive relationship but statistically insignificant and the relationship prevailed in most cases.

Angelidis (2010) applied on 24 countries of ECMs incorporated in international indicator of Morgan Stanly Company for international capital market from 31 December 1994 to 31 May 2007, depending on monthly data for unsystematic risks fluctuations and shares returns, the study found that the ratio between unsystematic risks fluctuation and the whole fluctuations are less in ECMs than developed markets. Since the developed markets are more efficient, also the study found no general trend for unsystematic risks fluctuations and a negative relationship between unsystematic risks fluctuations and shares expected returns. Study of Nartea et al (2011) applied to five markets of South East Asia including (Singapore, Malaysia, Thailand, Philippines, Indonesia) in different time periods between the countries as the beginning year differed where Singapore in January 1991, Malaysia was in April 1986, Thailand in March 1992, and the Indonesia in November 1990 and Philippines in September 1992 all end November 2007 depending on monthly data for unsystematic risks fluctuations and shares returns. And by following study of Ang et al (2009), the study found a positive relationship between unsystematic risks fluctuations and shares 
return in Thailand, Singapore, Malaysia, Indonesia and no statistical significant relationship in the Philippines.

Moreover, study of Wang (2013) applied to 607 Taiwanese stock market exchange companies from 2000 to 2011 aimed at reaching a limit for unsystematic risks that if passed through any unsystematic risks fluctuations increase such increase may not improve the expected. The study concluded the ability to expect market returns in the future through unsystematic risks, if unsystematic risks fluctuations are less than the final limit. But if fluctuations are more than the final limit, the relationship between unsystematic risks and the expected stocks returns shall not be statistically significant. In addition, many studies discussed the relationship between unsystematic risks and stock returns in the Chinese stock market, as there is the study of Drew et al (2004) which was applied on Shanghai stock market from December 1993 to December 2000, as there was a dependence on monthly data of stocks returns and unsystematic risks scales fluctuations, as the study proved that unsystematic risks play a big role in assets pricing. Also the study of Nartea et al (2013) as behavior of time sequence of unsystematic risks fluctuations and their role in pricing assets in china was studied from January 1994 to August 2011 and found no general attitude on the long term for unsystematic risks fluctuations in assets pricing and negative effects of unsystematic risks fluctuations in china. Also explained that investors preferring high fluctuation stocks with disability tend to implement effective diversification. Furthermore, the study of Deng et al (2014) discussed effects of unsystematic risks on the organisation's decisions through two main objectives : first represented in studying the relationship between unsystematic risks and the organisation's investment when managerial ownership is very weak, second represented in studying the relationship between projects diversification and unsystematic risks, the study found negative relationship between unsystematic risks and the organisation's investment, but in case of great reduction due to managerial ownership, the relationship shall not be statistically significant, also it was found that organisations prefer diversified projects to reduce their investment risks. But in case of great reduction due to managerial ownership, the relationship between unsystematic risks and diversification is positive.

In conclusion, from the above critical review, one can observe that at the level of the relationship between unsystematic risks fluctuations and stocks expected returns, the studies' results were subdivided into three different scenarios: first, studies proved negative relationship between unsystematic risks and returns, like study of Ang et al (2006) applied to the U.S, risks were measured by estimating unsystematic risks fluctuation as residuals standard deviation in Fama - Grench three factor model and study of Guo and Savickas (2006) applied also to the U.S by using quarterly data 1963 to 2002. And study of Guo and Savickas (2010) applied to 7 countries Canada, France, Italy, Japan, the U.K and U.S from January 1973 to December 2003.

Second scenario is represented by some studies that proved a positive relationship between unsystematic risks and returns like, study of Goyal and Santa Clara (2003) jiang and Lee (2006) as both studies applied to the U.S , on the aggregate level,.Also the same results were reached by Fu (2009) and Malkiel and Xu (2003) but at the firm level. And finally studies proved non statistical significant relationship between unsystematic risks and returns, such as, study of Bali and Cakici (2008), applied to the U.S as different fluctuations scales were used by using daily and monthly data from July 1926 to December 2002.

According to the critical review of the literature, the following hypotheses were drafted to achieve the study objectives:

\section{First Hypothesis:}

H1: Unsystematic risks effect differs from whole effect depending on stock size.

\section{Second Hypothesis:}

H2: Statistical significant the trend to the unsystematic risk in the period of 2006 to 2015 in the ESE.

\section{Third Hypothesis:}

\section{H3: The forecasting ability of the unsystematic risk in the ESE is significant and attainable.}

However, it is worth mentioning that researchers face a number of complicated positions and meanings regarding their research activity. Consequently, research design is affected by questions regarding the nature of knowledge and the nature of reality. The answer to the question of knowledge affects the implication of the way that methodology is acquired. Methodology, then, is a way of gaining knowledge about the world; trying to discover the task of finding out what is believed to be true. Departing from such discussion, the research methodology and design are discussed in the next section. 


\section{Methodology}

The whole research procedure is objectively constructed, and the results are regularly representative of the population being studied. The major advantages of the quantitative approach are control and precision. A high level of control is maintained throughout the design and sampling process, associated with precise quantitative measurements obtained. There is an additional advantage in relation to testing guides to statements regarding causation, given that the systematic manipulation of one variable can be revealed to have a direct causal effect on another when other variables have been controlled or eliminated (Blanche and Durrheim, 1999).

Volatility of the market can be estimated using historical volatility and implied volatility measures. Historical Volatility (or realised volatility) is a measure of price movements the underlying asset, while implied volatility market expectations regarding future volatility of the asset. The variance of asset returns is often used to calculate historical volatility. It is based on the closing prices of the reference period and completely ignores price information in the reference period. Consequently, another measure is the estimator of the range of historical volatility. Historical volatility may not precisely reflect the future volatility, and hence implied volatility is frequently calculated using option prices. An unsystematic risk is specific to an individual company. It is measured by the residual variance inventory in a given period using the error terms acquired from a standard asset pricing model such as the Fama-French three-factor model or the CAPM (see Ang, Hodrick, Xing and Zhang, 2006).

Therefore, the unsystematic risk is represented as firm specific risk. There are many methods for measuring unsystematic risks for instance: First: Direct method for measuring unsystematic risks depending on using residuals of factor model like CAPM and model of Fama and French (1993). Second: Indirect method by Campbell et al (2001) to calculate unsystematic risks which was used in the current study as it is the most applied approach in the finance literature methodology, for instance, Goyal and Santa Clara (2003), Wei and Zhang (2005) and Bali et al (2005), Angelidis and Tessoramatis (2008). This study uses the market model but under supposing that the betas are the same for all shares, unsystematic risks are calculated as difference between stock and market variances and market as lagged variable is represented which will be used to get rid of autocorrelation problem.

Therefore, the Indirect Method of Campbell et al.'s (2001) is used. The philosophy of the Indirect Method is based on that it decomposes the return on a "typical" stock into three components: the market wide return, an industry specific residual and a firm- specific residual. Founded on this return decomposition, constructing time series of volatility measures of the three components for a typical firm. So, one can define volatility measures that sum to the total return volatility reach firm specific risk series without having to estimate betas for firms or industries and without having to keep track of covariance.

To achieve the current study objectives, the current study community was to identify all firms incorporated in the Egyptian stock market from 2006 to 2015. The study sample is represented in firms of indicator (EGX100) and (EGX100) is the widest as it doesn't focus on a certain industry, accordingly it represents all sectors and selecting such period refers to the beginning of Egyptian exchange calculation of (EGX100) is 1 January 2006, data were obtained from Egypt company for information.

Monthly contrast for share A can be identified by using daily return data within the month as follows:

$$
V_{i t}=\sum_{d=1}^{D_{1}} r_{i d}^{2}+2 \sum_{d=1}^{D_{1}} r_{i d} r_{i d-1}
$$

As $D_{1}$ is number of trading days in month $T$ and $r_{i d}$ is return of share $A$ in day d. It's worth mentioning that this scale can't calculate stock variance perfectly as reservation period is short and daily data effect as not important, this was clear by studies of French, Scwert and Stambaugh (1987), Schwert (1989) and Goyal and Santa - Clara (2003), despite this fact French et al (1987) said that non synchronous trade may result in auto-correlated daily returns, accordingly the second term of equation No. (1), represents variances for share returns auto-correlation. Whose five views were removed within the month T while the part $2 \sum_{d=1}^{D_{1}} \boldsymbol{r}_{i d} \boldsymbol{r}_{\boldsymbol{i d - 1}}$ shall be removed from equation one, if Vi, $\mathrm{t}>0$ and under this frame the equally weighed total variance $\mathbf{T} \mathbf{V}_{\mathbf{1}}{ }^{\text {Equal }}$ can be calculated:

$$
T V_{t}^{\text {Equal }}=\frac{1}{N} \sum_{i=1}^{N_{t}} V_{i, t}
$$

As the total weighted variance shall be calculated by value $T V_{t}^{\text {Value }}$ as follows:

$$
T V_{t}^{V a l u e}=\sum_{i=1}^{N} \omega_{i, 1} V_{i, t} \text { and } \omega_{i, t}=\frac{v_{i, d_{t-1}}}{\sum_{i=1}^{N} v_{i, d_{1-t}}}
$$


As $\mathrm{N}$ is number of shares in the month $\mathrm{t}$ and $\boldsymbol{v}_{\boldsymbol{i}, \boldsymbol{d}_{\mathbf{1}-\boldsymbol{t}}}$ is the variance of stock A in day d in month $\mathrm{t}-1$.

While Xu and Malkiel (2001) suggests that the value weighted aggregate volatility of individual stocks consists of the volatility imparted by movements in the broad market index and aggregate unsystematic volatility, Angelidis and Tessoramatis (2008) pointed out that using the market model under the assumption that the betas of all securities against the market is one, the variance of stock i at time, can be decomposed in two parts: a systematic part which equals to the variance of the market, and unsystematic part which equals to the variance of the unsystematic return.

By using market model and supposing that betas for all shares are the same (Xu and Malkiel, 2001) variance A in time $t$ is $\boldsymbol{V}_{\boldsymbol{i}, \boldsymbol{t}}$ that can be subdivided to 2 parts:

First part: Systematic part and equals the market variance.

Second part: unsystematic risks part and variance of the market as follows:

$$
V_{i, t}=M V_{t}+I V_{i, t}
$$

Also total unsystematic variance can be calculated as follows:

$$
I V_{t}=T V_{t}-M V_{t}
$$

As $T \boldsymbol{V}_{\boldsymbol{t}}$ is the aggregate total volatility and can be calculated by individual shares variability by equation (2) or (3) as $\boldsymbol{M} \boldsymbol{V}_{\boldsymbol{t}}$ t represents market variance and the equally weighted unsystematic variance can be calculated as follows:

$$
I V_{t}^{\text {Equal }}=T V_{t}^{\text {Equal }}-M V_{t}
$$

And identifying the value - weighted unsystematic variance as follows:

$$
I V_{t}^{\text {Value }}=T V_{t}^{\text {Value }}-M V_{t}
$$

By using the equations (6), (7) three fluctuation scales can be made through three portfolios Big, Small and All by classifying stocks according to the previous month market value to three portfolios and to determine the portfolio size by using the method of Fama and French (1993) depending on median values.

\section{The Analysis of the Study}

Method of Campbell et al (2001) was used to calculate unsystematic risks and also in steps of testing hypothesis by using SPSS, the following results are presented:

\subsection{Descriptive Statistics of Data Volatilities}

Table 1. Descriptive statistics of different measurements for data volatilities

\begin{tabular}{llllllllllll}
\hline & Mean & Median & Max & Min & S.D. & Kurt & Skew & J.B. & $\mathbf{A R}_{\mathbf{1}}$ & $\mathbf{A R}_{\mathbf{6}}$ & $\mathbf{A R}_{\mathbf{1 2}}$ \\
\hline $\boldsymbol{T} \boldsymbol{V}_{\text {All }}^{\text {Equal }}$ & 0.03381 & 0.03382 & 0.12920 & 0.00470 & 0.02265 & 3.198 & 1.888 & 386.23 & 0.388 & 0.244 & 0.93 \\
$\boldsymbol{T} \boldsymbol{V}_{\text {BIG }}^{\text {EI }}$ & 0.03439 & 0.0285 & 0.185 & 0.0048 & 0.02785 & 3.348 & 1.468 & 312.68 & 0.485 & 0.485 & 0.006 \\
$\boldsymbol{T} \boldsymbol{V}_{\text {SMALL }}^{\text {Equal }}$ & 0.03667 & 0.02277 & 0.12770 & 0.00547 & 0.0267 & 3.670 & 1.874 & 245.71 & 0.477 & 0.177 & 0.004 \\
$\boldsymbol{T} \boldsymbol{V}_{\text {All }}^{\text {Value }}$ & 0.03691 & 0.0321 & 0.1141 & 0.0041 & 0.0211 & 7.411 & 2.701 & 410.11 & 0.321 & 0.116 & 0.031 \\
$\boldsymbol{T} \boldsymbol{V}_{\text {BIG }}^{\text {Value }}$ & 0.0192 & 0.0122 & 0.0962 & 0.022 & 0.02122 & 5.462 & 2.482 & 408.82 & 0.452 & 0.142 & 0.007 \\
$\boldsymbol{T} \boldsymbol{V}_{\text {SMALL }}^{\text {Value }}$ & 0.02893 & 0.0223 & 0.1053 & 0.0043 & 0.0163 & 6.233 & 2.393 & 121.32 & 0.431 & 0.133 & 0.002 \\
$\boldsymbol{I} \boldsymbol{V}_{\text {All }}^{\text {Equal }}$ & 0.03105 & 0.02356 & 0.1165 & 0.0045 & 0.02555 & 5.055 & 2.453 & 375.55 & 0.455 & 0.095 & 0.004 \\
$\boldsymbol{I} \boldsymbol{V}_{\text {BIG }}^{\text {Equal }}$ & 0.03014 & 0.0224 & 0.11744 & 0.00314 & 0.02704 & 3.843 & 2.234 & 309.44 & 0.446 & 0.042 & 0.006 \\
$\boldsymbol{I} \boldsymbol{V}_{\text {SMALL }}^{\text {Equa }}$ & 0.03312 & 0.0232 & 0.12540 & 0.0254 & 0.022627 & 5.842 & 2.625 & 354.62 & 0.302 & 0.082 & 0.002 \\
$\boldsymbol{I} \boldsymbol{V}_{\text {All }}^{\text {Value }}$ & 0.02555 & 0.0259 & 0.11125 & 0.0045 & 0.02135 & 10.952 & 3.345 & 456.53 & 0.315 & 0.065 & 0.015 \\
$\boldsymbol{I} \boldsymbol{V}_{\text {BIG }}^{\text {Value }}$ & 0.0256 & 0.0153 & 0.154 & 0.005 & 0.0275 & 17.459 & 3.858 & 445.53 & 0.351 & 0.15 & 0.035 \\
$\boldsymbol{I} \boldsymbol{V}_{\text {SMALL }}^{\text {Value }}$ & 0.02744 & 0.0204 & 0.1334 & 0.0044 & 0.044 & 13.494 & 3.264 & 84.43 & 0.444 & 0.084 & 0.004 \\
MV & 0.0007 & 0.0007 & 0.007 & 0.0002 & 0.0002 & 32.577 & 4.887 & 113.52 & 0.493 & 0.022 & 0.008 \\
\hline
\end{tabular}

SD is the standard deviation, Skew is Skewness, Kurt is Kurtosis, J.B is Jarque - Bera test, AR1 AR6, AR12, are Autogressive coefficient for orders $1,6,12$. 
Table I shows that unsystematic volatility is the largest component of total volatility irrespective of the size, similar to findings of Campbell et al. (2001), Goyal and Santa Clara(2003) for the US market and Angelidis and Tessaromatis (2008) for the UK market. The average idiosyncratic volatility represents between $70 \%$ and $95 \%$ of total average volatility and therefore market variance is only fraction of the total variance. Moreover, also study of Fazil and Lpek (2013) found that unsystematic volatilities represent between $64.62 \%$ to $98.17 \%$ of the whole volatilities while market variance showed a small fraction of total variance. The total and unsystematic volatility variances of SMALL stocks are slightly higher than BIG stocks. Correlations between total and idiosyncratic volatilities of ALL, BIG and SMALL take considerably high values which are between $95.65 \%$ and $99.70 \%$. On the other hand, correlations between volatility measures of the portfolios and market variance are relatively lower, in the range of $\% 52.19$ and $\% 65.13$.

The results proved high equally weighted volatile values than value weighted volatilities, big stock volatiles are similar to All stocks volatilities. Also results proved that small shares volatilities values are higher than Big stocks volatilities variables. Time series analysis models were represented through Autogressive model as the following table explains results of AR 12, AR 6, and AR1, for Autocorrelation coefficients for orders 6, 1, and12.

\subsection{Unsystematic Risks Effect Differs from Whole Effect Depending on Share Size}

Table No. (2) Proves that a coefficient of AR (1) tends to 0.5 where AR (12) tends to zero to prove model suitability for the analysis. Also, Table (2) shows a positive skewness which means that these volatilities are not normally distributed and a higher Kurtosis higher than it should be to a normal distribution (more than 3 times). The Jarque Bera (JB) test were supported by skewness and kurtosis results and is calculated as follows:

$$
J B=\frac{n}{6}\left[S^{2}+\frac{1}{4}(k-3)^{2}\right]
$$

As $\mathrm{N}$ represents sample subjects number, $\mathrm{S}$ represents skewness and $\mathrm{K}$ represent kurtosis. The normal distribution hypothesis was refused for volatilities sequences at significance level 1\%. Table No. (2) Clarifies correlation between different risks measurements in Egyptian stock markets for all Big and Small portfolios from 2006 to 2015. The table represents bivariate correlation between different risks measurements which were log transformed. Based on the correlation matrix, the size effect could be analysed, that is it is clear that table No. 2 shows a strong correlation between Big stocks total volatilities measurements and all stocks volatilities measurements as values are very close to 1 . Where Small stocks volatilities correlations and all stocks volatilities were relatively weak when value weighted are equal to 0.44 . This behavior could be possibly explained by increased Small stocks average volatilities than average volatilities of Big stocks.

Table 2. Matrix of correlation between different risks measurements

\begin{tabular}{|c|c|c|c|c|c|c|c|c|c|c|c|c|}
\hline & $T V_{\text {All }}^{\text {Equal }}$ & $T V_{B I G}^{\text {Equal }}$ & $T V_{S M A L I}^{\text {Equal }}$ & $T V_{\text {All }}^{\text {Value }}$ & $V_{\text {BIG }}^{\text {Value }}$ & $T V_{\text {SMALI }}^{\text {Value }}$ & $I V_{\text {All }}^{\text {Equal }}$ & $I V_{B I G}^{\text {Equal }}$ & $I V_{S M A L L}^{\text {Equal }}$ & $I V_{\text {All }}^{\text {Value }}$ & $I V_{B I G}^{\text {Value }}$ & $I V_{\text {SMALL }}^{\text {Value }}$ \\
\hline$T V_{\text {All }}^{\text {Equal }}$ & 1.00 & & & & & & & & & & & \\
\hline$T V_{B I G}^{\text {Equal }}$ & 0.95 & 1.00 & & & & & & & & & & \\
\hline$T V_{S M A L I}^{\text {Equal }}$ & 0.62 & 0.75 & 1.00 & & & & & & & & & \\
\hline$T V_{\text {All }}^{\text {Value }}$ & 0.63 & 0.83 & 0.63 & 1.00 & & & & & & & & \\
\hline$T V_{B I G}^{V a l u e}$ & 0.92 & 0.64 & 0.72 & 0.82 & 1.00 & & & & & & & \\
\hline$T V_{S M A L I}^{V a l u e}$ & 0.63 & 0.58 & 0.83 & 0.67 & 0.56 & 1.00 & & & & & & \\
\hline$I V_{A l l}^{\text {Equal }}$ & 0.71 & 0.97 & 0.71 & 0.71 & 0.97 & 0.85 & 1.00 & & & & & \\
\hline$I V_{B I G}^{\text {Equal }}$ & 0.97 & 0.54 & 0.85 & 0.96 & 0.75 & 0.65 & 0.98 & 1.00 & & & & \\
\hline$I V_{S M A L L}^{E q u a l}$ & 0.63 & 0.63 & 0.86 & 0.73 & 0.74 & 0.81 & 0.75 & 0.84 & 1.00 & & & \\
\hline$I V_{A l l}^{V a l u e}$ & 0.82 & 0.97 & 0.72 & 0.86 & 0.97 & 0.54 & 0.65 & 0.98 & 0.52 & 1.00 & & \\
\hline$I V_{B I G}^{V a l u e}$ & 0.97 & 0.72 & 0.86 & 0.97 & 0.65 & 0.72 & 0.99 & 0.76 & 0.81 & 0.99 & 1.00 & \\
\hline$I V_{S M A L L}^{V a l u e}$ & 0.98 & 0.81 & 0.71 & 0.62 & 0.56 & 0.74 & 0.52 & 0.98 & 0.53 & 0.44 & 0.51 & 1.00 \\
\hline MV & 0.41 & 0.33 & 0.43 & 0.45 & 0.38 & 0.47 & 0.43 & 0.42 & 0.34 & 0.41 & 0.45 & 0.21 \\
\hline
\end{tabular}

Study of Fazil and Ipek (2013) was followed to measure big and small stocks volatilities effect on all volatilities to 
know the size effect on total volatilities by using Logarithmic formula of different volatilities. Since this Logarithmic formula lead to a low skewness and Kurtosis level to make it tends to normal distribution. The following is a model of equal weighted volatility in equation number 8 and value weighted volatility No. 9:

$$
\begin{aligned}
& T V_{t}^{\text {Value }}=0.3111+0.2445 T V_{B I G}^{\text {Equal }}+0.65987 T V_{\text {SMALL }}^{\text {Equal }}+0.0231 \mathrm{MV}+0.01258 \\
& \begin{array}{lllll}
(0.0) & (0.0) & (0.0) & (0.0) & R^{2}=89.6
\end{array} \\
& T V_{t}^{\text {Value }}=0.3171+0.2958 T V_{B I G}^{\text {Equal }}+0.55987 T V_{\text {SMALL }}^{\text {Equal }}+0.0431 \mathrm{MV}+0.01358 \\
& \begin{array}{lllll}
(0.0) & (0.0) & (0.0) & (0.0) & R^{2}=89.8
\end{array}
\end{aligned}
$$

From equations 9,10 it was clear that model ability to expect as R2 in out weighting model reached equally $89.8 \%$ and equal out weighting model $89.6 \%$. Also it was clear that small stocks volatilities, whether outweighed equally or by value contribute in all volatilities variables whether out weighted or by value reached $55.98 \%$ and $65.98 \%$, respectively. Unlike big stocks volatilities, which were low as contributing in all variables whether out weighted equally or by value respectively at $29.58 \%, 24.45 \%$.

\subsection{Verifying the Trend to the Unsystematic Risk in the Period of 2006 to 2015 in the ESE.}

To analyse regression, unit root test was made (as it aims at investigating time sequence trend) characteristics for unsystematic volatilities from 2006 to 2015) identify time sequences stationary (as time sequences are stationary if their average, data and variables are stable by time) for different volatilities or not and knowing the studies time sequences and to verify valid and logic results, this is possible through unit root tests like Dickey and Fuller (1979) and

\begin{tabular}{|c|c|c|c|c|c|c|c|c|}
\hline \multicolumn{5}{|c|}{ Dickey and Fuller Statistics } & \multicolumn{4}{|c|}{ Philips - Perron Statistics } \\
\hline \multicolumn{2}{|c|}{ Intercept } & \multicolumn{3}{|c|}{ Intercept and Trend } & \multicolumn{2}{|c|}{ Intercept } & \multicolumn{2}{|c|}{ Intercept and Trend } \\
\hline & t-stat & $\mathrm{p}$-value & t-stat & p-value & t-stat & p-value & t-stat & pvalue \\
\hline IV $_{\text {All }}^{\text {Equal }}$ & $2.541-$ & 0.004 & $3.217-$ & 0.0231 & $3.214-$ & 0.003 & 3.577- & 0.0351 \\
\hline IV $_{\text {BIG }}^{\text {Equal }}$ & $3.361-$ & 0.002 & 0.85 & $2.474-$ & 0.013 & 0.005 & $3.264-$ & 0.045 \\
\hline IV Equal & $2.372-$ & 0.005 & 2.346- & 0.051 & $2.415-$ & 0.002 & 2.316- & 0.022 \\
\hline$I_{\text {All }}^{\text {Value }}$ & $3.445-$ & 0.003 & $3.371-$ & 0.013 & $3.571-$ & 0.001 & 2.321- & 0.057 \\
\hline IV $_{\text {BIG }}^{\text {Value }}$ & $3.754-$ & 0.002 & $3.317-$ & 0.052 & $2.514-$ & 0.004 & 3.847- & 0.023 \\
\hline $\begin{array}{l}\text { IV Value } \\
\text { SMALL }\end{array}$ & $2.387-$ & 0.001 & $2.251-$ & 0.031 & $3.269-$ & 0.004 & 2.961- & 0.051 \\
\hline MV & $2.448-$ & 0.001 & $3.34-$ & 0.043 & $2.651-$ & 0.003 & $2.164-$ & 0.013 \\
\hline
\end{tabular}
Philips - Perron (1988), and table number 3 clarifies unit root test by using test of Dicky Fuller and Philips - Perron as follows:

Table 3. Time sequences stationary test of different volatiles measures

Table No. 3 clarifies unit roots tests for different volatilities measurements which were log transformed results of the table prove that $\mathrm{T}$ statistics values exceed tabular value, accordingly they are statistically significant. The fact that the coefficient of the trend of all measures of unsystematic volatility is not statistically significant shows unsystematic volatility had not a rising or falling trend in period of 2006-2015. On the other hand, the coefficient of market variance is negative and statistically significant at 5\% confidence level. This finding points out a very slow decreasing trend of market volatility in this period. Our finding about time trend of unsystematic volatility of ESE is consistent with of Fazil and Ipek's findings (2013) which report no significant increase in firm specific volatility in Turkish market.

\subsection{Investigating the forecasting ability of the unsystematic risk in the ESE.}

In contradiction of standard asset pricing theories which claim that unsystematic risk is not priced because of diversification ability of investors, it is possible to test whether unsystematic risk is a significant predictor or not, in 
forecasting of future return. It was depended on methods of Angelidis and Tessoramatis (2008) and Goyal and Santa Clara (2003) model which is employed by this study. We investigate the relationship between volatility and subsequent stock returns in ESE, by regressing stock returns on various measures of lagged volatility.

$$
r_{-}(t+1)=\alpha+\beta X \_t+\varepsilon_{-}(t+1)
$$

As $\mathrm{rt}+1$ are logarithm of monthly returns of market portfolio in $\mathrm{t}+1$.

$\mathrm{X} 1$ includes different volatilities (market volatilities, unsystematic volatilities) lagged volatility were used as obtained results are the same in case of using values of volatilities extracted from ARMA (1990) Schwert, logarithmic formulas were used for different volatilities and transformation to logarithmic formula may reduce Skewness level and kurtosis to make them tend to natural distribution also the second row of table consists of Pvalues adjusted for Newey and West (1987) used for correction in Variation and auto correlation for all regression values. It is clear from table No. 4 disability of different volatilities to expect stock returns as R2 was not high, these studies agree with studies of Angelidis and Tesseoramatis (2008), Fazil and Ipek (2013).

Table 4. Testing ability of measurements of unsystematic volatilities on expecting stock returns

\begin{tabular}{|c|c|c|c|c|c|c|c|c|c|}
\hline \multicolumn{10}{|c|}{ Panel A. Forecasts of the capitalization weighted market return } \\
\hline Equations & Constant & $\begin{array}{l}\text { IV } \\
\text { Equal } \\
\text { ALL }\end{array}$ & $\begin{array}{l}\text { IV } \\
\text { Equal } \\
\text { BIG }\end{array}$ & $\begin{array}{l}\text { IV Equal } \\
\text { SMALL }\end{array}$ & $\begin{array}{l}\text { IV } \\
\text { Value } \\
\text { ALL }\end{array}$ & $\begin{array}{l}\text { IV } \\
\text { Value } \\
\text { BIG }\end{array}$ & $\begin{array}{l}\text { IV } \\
\text { Value } \\
\text { SMAL } \\
\text { L }\end{array}$ & MV & $R^{2}$ \\
\hline $\begin{array}{l}1 \\
\text { p-value }\end{array}$ & $\begin{array}{l}0.0314 \\
0.32\end{array}$ & $\begin{array}{l}0.0035 \\
0.62\end{array}$ & & & & & & & $25 \%$ \\
\hline $\begin{array}{l}2 \\
\text { p-value }\end{array}$ & $\begin{array}{l}0.0034- \\
0.97\end{array}$ & & $\begin{array}{l}0.0029 \\
0.56\end{array}$ & & & & & & $19 \%$ \\
\hline $\begin{array}{l}3 \\
\text { p-value }\end{array}$ & $\begin{array}{l}0.0092- \\
0.74\end{array}$ & & & $\begin{array}{l}0.0069 \\
0.39\end{array}$ & & & & & $6 \%$ \\
\hline $\begin{array}{l}4 \\
\text { p-value }\end{array}$ & $\begin{array}{l}0.0194 \\
0.46\end{array}$ & & & & $\begin{array}{l}0.0020 \\
0.75\end{array}$ & & & & $27 \%$ \\
\hline $\begin{array}{l}5 \\
\text { p-value }\end{array}$ & $\begin{array}{l}0.0352 \\
0.37\end{array}$ & & & & & $\begin{array}{l}0.0014 \\
0.76\end{array}$ & & & $29 \%$ \\
\hline $\begin{array}{l}6 \\
\text { p-value }\end{array}$ & $\begin{array}{l}0.311 \\
0.19\end{array}$ & & & & & & $\begin{array}{l}0.0038 \\
0.63\end{array}$ & & $16 \%$ \\
\hline $\begin{array}{l}7 \\
\text { p-value }\end{array}$ & $\begin{array}{l}0.0094 \\
0.84\end{array}$ & & & & & & & $\begin{array}{l}0.0017 \\
0.53\end{array}$ & $25 \%$ \\
\hline $\begin{array}{l}8 \\
\text { p-value }\end{array}$ & $\begin{array}{l}0.0018 \\
0.74\end{array}$ & & $\begin{array}{l}0.0028 \\
0.58\end{array}$ & & & & & $\begin{array}{l}0.0024 \\
0.46\end{array}$ & $22 \%$ \\
\hline $\begin{array}{l}9 \\
\text { p-value }\end{array}$ & $\begin{array}{l}0.0097 \\
0.78\end{array}$ & & & $\begin{array}{l}0.0034 \\
0.45\end{array}$ & & & & $\begin{array}{l}0.0025 \\
0.37\end{array}$ & $23 \%$ \\
\hline $\begin{array}{l}10 \\
p \text {-value }\end{array}$ & $\begin{array}{l}0.0092 \\
0.72\end{array}$ & & $\begin{array}{l}0.0031 \\
0.47\end{array}$ & $\begin{array}{l}0.0046 \\
0.39\end{array}$ & & & & & $23 \%$ \\
\hline $\begin{array}{l}11 \\
p \text {-value }\end{array}$ & $\begin{array}{l}0.324 \\
0.37\end{array}$ & & & & & $\begin{array}{l}0.0021 \\
0.27\end{array}$ & & $\begin{array}{l}0.0031 \\
0.21\end{array}$ & $23 \%$ \\
\hline $\begin{array}{l}12 \\
p \text {-value }\end{array}$ & $\begin{array}{l}0.0024- \\
0.64\end{array}$ & & & & & & $\begin{array}{l}0.023 \\
0.23\end{array}$ & $\begin{array}{l}0.0025 \\
0.26\end{array}$ & $23 \%$ \\
\hline $\begin{array}{l}13 \\
p \text {-value }\end{array}$ & $\begin{array}{l}0.0096- \\
0.64\end{array}$ & & & & & $\begin{array}{l}0.0027 \\
0.26\end{array}$ & $\begin{array}{l}0.0031 \\
0.28\end{array}$ & & \\
\hline
\end{tabular}




\begin{tabular}{|c|c|c|c|c|c|c|c|c|c|}
\hline \multicolumn{10}{|c|}{ Panel B. Forecasts of the capitalization weighted market return } \\
\hline Equations & Constant & $\begin{array}{l}\text { IV Equal } \\
\text { All }\end{array}$ & $\begin{array}{l}\text { IV } \\
\text { Equal } \\
\text { BIG }\end{array}$ & $\begin{array}{l}\text { IV Equal } \\
\text { SMALL }\end{array}$ & $\begin{array}{l}\text { IV } \\
\text { Value } \\
\text { ALL }\end{array}$ & $\begin{array}{l}\text { IV } \\
\text { Value } \\
\text { BIG }\end{array}$ & $\begin{array}{l}\text { IV } \\
\text { Value } \\
\text { SMAL } \\
\text { L }\end{array}$ & MV & $R^{2}$ \\
\hline 1 & 0.0468 & 0.0026 & & & & & & & $13 \%$ \\
\hline p-value & 0.19 & 0.54 & & & & & & & \\
\hline $\begin{array}{l}2 \\
p \text {-value }\end{array}$ & $\begin{array}{l}0.0687 \\
0.06\end{array}$ & & $\begin{array}{l}0.0017 \\
0.47\end{array}$ & & & & & & $22 \%$ \\
\hline $\begin{array}{l}3 \\
\text { p-value }\end{array}$ & $\begin{array}{l}0.0642 \\
0.04\end{array}$ & & & $\begin{array}{l}0.0027 \\
0.21\end{array}$ & & & & & $12 \%$ \\
\hline $\begin{array}{l}4 \\
\text { p-value }\end{array}$ & $\begin{array}{l}0.0365 \\
0.31\end{array}$ & & & & $\begin{array}{l}0.0026 \\
0.24\end{array}$ & & & & $25 \%$ \\
\hline $\begin{array}{l}5 \\
p \text {-value }\end{array}$ & $\begin{array}{l}0.0425 \\
0.34\end{array}$ & & & & & $\begin{array}{l}0.0018 \\
0.35\end{array}$ & & & $6 \%$ \\
\hline $\begin{array}{l}6 \\
\text { p-value }\end{array}$ & $\begin{array}{l}0.0523 \\
0.18\end{array}$ & & & & & & $\begin{array}{l}0.0039 \\
0.54\end{array}$ & & $26 \%$ \\
\hline $\begin{array}{l}7 \\
\text { p-value }\end{array}$ & $\begin{array}{l}0.0712 \\
0.06\end{array}$ & & & & & & & $\begin{array}{l}0.0021 \\
0.43\end{array}$ & $27 \%$ \\
\hline $\begin{array}{l}8 \\
\text { p-value }\end{array}$ & $\begin{array}{l}0.0624 \\
0.041\end{array}$ & & $\begin{array}{l}0.0022 \\
0.58\end{array}$ & & & & & $\begin{array}{l}0.0026 \\
0.41\end{array}$ & $18 \%$ \\
\hline $\begin{array}{l}9 \\
\text { p-value }\end{array}$ & $\begin{array}{l}0.0634 \\
0.0124\end{array}$ & & & $\begin{array}{l}0.00350 \\
41\end{array}$ & & & & $\begin{array}{l}0.0024 \\
0.31\end{array}$ & $18 \%$ \\
\hline $\begin{array}{l}10 \\
p \text {-value }\end{array}$ & $\begin{array}{l}0.035 \\
0.227\end{array}$ & & $\begin{array}{l}0.0024 \\
0.43\end{array}$ & & & & & & $25 \%$ \\
\hline $\begin{array}{l}11 \\
p \text {-value }\end{array}$ & $\begin{array}{l}0.0357 \\
0.31\end{array}$ & & & & & $\begin{array}{l}0.0024 \\
0.21\end{array}$ & & $\begin{array}{l}0.0027 \\
0.26\end{array}$ & $16 \%$ \\
\hline $\begin{array}{l}12 \\
p \text {-value }\end{array}$ & $\begin{array}{l}0.034- \\
0.91\end{array}$ & & & & & & $\begin{array}{l}0.0027 \\
0.28\end{array}$ & $\begin{array}{l}0.0023 \\
0.27\end{array}$ & $22 \%$ \\
\hline $\begin{array}{l}13 \\
\text { p-value }\end{array}$ & $\begin{array}{l}0.0086- \\
0.57 \\
\end{array}$ & & & & & $\begin{array}{l}0.0031 \\
0.22 \\
\end{array}$ & $\begin{array}{l}0.0027 \\
0.31 \\
\end{array}$ & & $22 \%$ \\
\hline
\end{tabular}

This is inconsistent with theoretical models such as the CAPM, which predict a significant relation, but consistent with the results of studies for developed equity markets. The volatility effect appears to be growing stronger over time, which we argue might be related to the increased delegated portfolio management in ECMs.

\section{Conclusion}

While the majority of the empirical finance research has favored developed markets, partly due to the accessibility of high-quality long-term historical data, ECMs have attracted a significant attention in the past 30 years. Many of these studies have addressed the issue of market liberalisation and its impact on equity return and volatility. Some studies have applied well-established models on emerging market data, but it appears that there have only been a few attempts for analysing theoretical models catered towards this segment of the world economy. ECMs have evolved significantly over time. Although they are not fully integrated with developed markets, the correlation between emerging market equity returns and those of developed markets are much higher than before.

Our findings suggest that unsystematic volatility is the most essential component of total volatility and displayed a different trend than the expected, eventhough market volatility has a slow decreasing trend in this period. We also foud that small size stocks have a slightly higher volatility than the big ones but both portfolios have similar unsystematic risk behavior. Finally, our analyses about the predictive ability of various measures of unsystematic risk showed evidence that unsystematic risk volatility is not a significant predictor of future return in ESE.

Therefore, the hypothesis regarding the ability to forecast the unsystematic risk in the ESE is rejected. The reason for 
the non-normality can impact asset allocation is that the downside risk associated with different asset classes is very different. Most obviously, equity and equity type asset classes entail greater degrees of downside risk like fixed income type investments. Hence, because the downside risk characteristics of different asset classes are different-and cannot be accounted for using traditional modeling techniques or risk measures such as standard deviation - analysing the impact of unsystematic risk on stock return in this study is motivated by non-normal framework and must also be different from the traditional framework. Hence, the authors believe that investors dealing within the Egyptian Stock Exchange (ESE) need to quantitatively incorporate the impact of non-normality into the stock valuations techniques.

A failure to control for other risk factors in the ESE and ECMs in general, might explain the indefinability of such evidence. One of these risk factors is the book-to-equity ratio, the ratio of the value of a firm's tangible assets (e.g., machinery, land) to that firm's market value. Stocks with high book-to-equity ratios (i.e., relatively low market values) tend to be risky investments, and investors require high expected returns for holding these stocks. Thus, book-to-equity ratios could be essential determinants of stock returns in ECMs.

Finally, the findings of this study are applicable for global fund managers who plan to develop ECMs strategies for asset allocation. On an overall basis, ECMs seem to be efficient regarding to cross-sectional volatility-based information. From an academic point of view, the FF model seems to be a better asset pricing tool compared to CAPM for the pricing of cross-sectional volatility sorted portfolios. The study contributes to portfolio management as well as market efficiency literature for ECMs. Lastly, there appears to be a need for comprehensive longitudinal studies of the dynamic relationships in order to explain how ECMs returns and volatilities can still be higher than those of developed markets although they appear to be more correlated among each other.

\section{References}

Ang, A., Hodrick, R. J., Xing, Y., \& Zhang, X. (2006). The cross-section of volatility and expected returns. Journal of Finance, 61, 259-299. https://doi.org/10.1111/j.1540-6261.2006.00836.x

Ang, A., Hodrick, R. J., Xing,Y., \& Zhang , X. (2009). High idiosyncratic volatility and low returns: International and further U.S. evidence. Journal of Financial Analysis, 17, 539-556.

Angelidis, T. (2010). Idiosyncratic risk in emerging markets. The Financial Review, 45, 1053-1078. https://doi.org/10.1111/j.1540-6288.2010.00285.x

Angelidis, T., \& Tessaromatis, N. (2008). Idiosyncratic volatility and Equity Returns: UK evidence. International Review of Financial Analysis, 17, 539-556. https://doi.org/10.1016/j.irfa.2006.10.006

Bali, Turan, \& Cakici, Nusret. (2008). Idiosyncratic Volatility and the Cross Section of Expected Returns. Journal of Financial and Quantitative Analysis, 43, 29-58. https://doi.org/10.1017/S002210900000274X

Bekeart, Greet, \& Harvey, Campbell. (1997). Emerging Equity Market Volatility. Journal of Financial Economics, 43, 29-77. https://doi.org/10.1016/S0304-405X(96)00889-6

Blanche, Martin, Durrheim, Kevin, \& Painter, Desmond. (1999). Research in practice (2nd ed.). UCT press.

Brandt, M. W., Brav, A., Graham, J., \& Kumar, A. (2010). The Idiosyncratic Volatility Puzzle: Time Trend or Speculative Episodes?. The Review of Financial Studies, 23, 863-899. https://doi.org/10.1093/rfs/hhp087

Brown, Gregory, \& Kapadia, Nishad. (2007). Firm-Specific Risk and Equity Market Development. Journal of Financial Economics, 84, 358-388. https://doi.org/10.1016/j.jfineco.2006.03.003

Campbell, J. Y., Lettau, M., Malkiel, B. G., \& Xu, Y. (2001). Have individual stocks become more volatile? An empirical exploration of idiosyncratic risk. Journal of Finance, 56, 1-44. https://doi.org/10.1111/0022-1082.00318

Cao, C., Simin, T., \& Zhao, J. (2008). Can growth options explain the trend in idiosyncratic risk. Review of Financial Studies, 21, 2599-2633. https://doi.org/10.1093/rfs/hhl039

Chiang, Thomas C. \& Doong, Shuh-Chyi. (2001). Empirical Analysis of Stock Returns and Volatility: Evidence from Seven Asian Stock Markets Based on TAR-GARCH Model. Review of Quantitative Finance and Accounting, 17, 301-318. https://doi.org/10.1023/A:1012296727217

Dennis, P., \& Strickland, D. (2004). The determinants of idiosyncratic volatility. University Of North Carolina Working Paper.

DeSantis, G., \& S. Imrohoroglu. (1997). Stock Returns and Volatility in Emerging Financial Markets. Journal of 
International Money and Finance, 16, 561-579. https://doi.org/10.1016/S0261-5606(97)00020-X

Dickey, David, \& Fuller. Wayne. (1979). Distribution of the Estimators for Autoregressive Time Series with a Unit Root. Journal of the American Statistical Association, 74, 427-431.

Douglas, E. (1969). Risk in the equity markets: An empirical appraisal of market efficiency, Yale Economic Essays, 9, 3-45.

Drew, M. E., Naughton, T., \& Veeraraghavan, M. (2004). Is idiosyncratic volatility priced? Evidence from the Shanghai stock exchange. Review of Financial Analysis, 13, 349-366. https://doi.org/10.1016/j.irfa.2004.02.027

Drew, Micheal, \& Veeraraghavan, Madhu. (2002). A Closer Look at the Size and Value Premium in Emerging Markets: Evidence from the Kuala Lumpur Stock Exchange. Journal of the East Asian Economic Association, 16, 337-351. https://doi.org/10.1111/1467-8381.00156

Drew, M., Malin, M., Naughton, T., \& Veeraraghavan, M. (2006). Idiosyncratic volatility and security returns: evidence from Germany and United Kingdom. Studies in Economics and Finance, 23, 80-93.

Fama. Eugene, \& MacBetch, James. (1973). Risk, Return, and Equilibrium: Empirical Tests. The Journal of Political Economy, 81, 607-636. https://doi.org/10.1086/260061

Fazil, Gökgöz \& İpek, Altinta. (2013). Does Idiosyncratic Volatility Matter in the Emerging Markets? Istanbul Stock Exchange Evidence. Journal of Economic Research, 26, 133-150. https://doi.org/10.1080/1331677X.2013.11517626

Fink, J., Fink, K., \& He, H. (2010). Idiosyncratic volatility measures and expected return. James Madison University Working Paper. https://doi.org/10.2139/ssrn.1692315

French, K. R., Schwert, G. W., \& Stambaugh, R. F. (1987). Expected stock returns and volatility. Journal of Financial Economics, 19, 3-29. https://doi.org/10.1016/0304-405X(87)90026-2

Fu, F. (2009). Idiosyncratic risk and the cross- section of expected returns. Journal of Financial Economics, 29, 24-37. https://doi.org/10.1016/j.jfineco.2008.02.003

Glosten, L. R., Jagannathan R., \& Runkle D. E. (1993). On the relation between the expected value and the volatility of the nominal excess return on stocks. Journal of Finance, 48, 1779-1801.

Goyal, A., \& Santa-Clara, P. (2003). Idiosyncratic risk matters. The Journal of Finance, 58, 975-1007. https://doi.org/10.1111/1540-6261.00555

Hang, Wei \& Liu, Can. (2005). The Impact of Environmental Policy on Household Income and Activity Choice: Evidence from Sandstorm Source Control Program in North China, Annual meeting, July 24-27, Providence, RI 19482. American Agricultural Economics Association (New Name 2008: Agricultural and Applied Economics Association).

Hui, Guo, \& Robert, Savickas. (2006). Understanding Stock Return Predictability.

Irvine, Paul, \& Pontiff, Jeffrey. (2009). Idiosyncratic Return Volatility, Cash Flows, and Product Market Competition .The Review of Financial Studies, 22(3),1149-1177. https://doi.org/10.1093/rfs/hhn039

Lee, Cheng, Chen, Gong \& Rui. (2001). Oliver.STOCK RETURNS AND VOLATILITY ON CHINA'S STOCK MARKETS. The Journal Of financial Research, 24, 523-543. https://doi.org/10.1111/j.1475-6803.2001.tb00829.x

Lehmann, B. (1990). Residual risk revisited. Journal of Econometrics, 45, 71-97. https://doi.org/10.1016/0304-4076(90)90094-A

Lintner, J. (1965). The valuation of risk assets and the selection of risky investments in stock portfolios and capital budgets. Review of Economics and Statistics, 47, 13-37. https://doi.org/10.2307/1924119

Malkiel, B., \& Xu, Y. (1997).Risk and Return revisited. Journal of Portofolio Management, 23, 9-14. https://doi.org/10.3905/jpm.1997.409608

Masry, M. (2016b). The Impact of Institutional Ownership on the Performance of Companies Listed In the Egyptian Stock Market. IOSR Journal of Economics and Finance (IOSR-JEF), 7, 5-15.

Masry, M. (2017). The Impact of Technical Analysis on Stock Returns in an Emerging Capital Markets (ECM's) Country: Theoretical and Empirical Study. International Journal of Economics and Finance, 9, 91-107. https://doi.org/10.5539/ijef.v9n3p91 
Merton, R. (1987). A simple model of capital market equilibrium with incomplete information. Journal of Finance, 42, 483-510. https://doi.org/10.1111/j.1540-6261.1987.tb04565.x

Miller, M., \& Scholes, M. (1972). Rates and Return in relation to risk: A re-examination of some recent findings, in Michael C. Jensen, ed. Studies in the Theory of Capital Markets. New York, 47-78.

Miralles, J., Miralles, M., \& Miralles, Q. (2012). Asset pricing with idiosyncratic risk: The Spanish case. International Review of Economics and Finance, 21, 261-271. https://doi.org/10.1016/j.iref.2011.07.004

Nartea, Gillbert, Ward, Bert \& Yao, Lee. (2011). Idiosyncratic volatility and cross-sectional stock returns in Southeast Asian stock markets .Journal of Accounting \& Finance, 51, 1031-1054. https://doi.org/10.1111/j.1467-629X.2010.00384.x

Newey, W., \& K. West. (1987). A simple positive semi-definite, heteroskedasticity and autocorrelation consistent covariance matrix.Econometrica, 55, 703-708. https://doi.org/10.2307/1913610

Phillips, P., \& Perron, P. (1988). Testing for Unit Roots in Time Series Regression. Biometrika, 75, 335-346. https://doi.org/10.1093/biomet/75.2.335

Scwert, G. (1989). Why Does Stock Market Volatility Change Over Time?. The Journal of Finance, 44, 1115-1153. https://doi.org/10.1111/j.1540-6261.1989.tb02647.x

Shin, J. (2005). Stock returns and volatility in emerging stock markets. International Journal of Business and Economics, 4, 31-43.

Vozlyublennaia, Nadia. (2011). Do firm characteristics matter for the dynamics of idiosyncratic risk?, Journal of International Financial Markets, Institutions and Money, 27, 35-46. https://doi.org/10.1016/j.intfin.2013.07.006

Vozlyublennaia, N. (2013). Do firm characteristics matter for the dynamics of idiosyncratic risk?. Journal of International Financial Markets Institutions and Money, 27, 35-46. https://doi.org/10.1016/j.intfin.2013.07.006

Wang, M. (2013). Idiosyncratic Volatility and the Expected Stock Returns for Exploring the relationship with Panel Threshold Regression. Asia-Pacific Financial Markets, 20, 113-129. https://doi.org/10.1007/s10690-012-9161-0 